\title{
MATHEMATICAL MODEL OF THE EMISSIONS OF A SELECTED VEHICLE
}

\section{RADIM MATUŠŮ, JOSEF MIK, MARTIN KOTEK}

Czech University of Life Sciences Prague, Faculty of Engineering, Kamýcká 129, Praha 6, 165 21, Czech Republic

E-mail: matusu@tf.czu.cz, jmik@tf.czu.cz, kotekm@oikt.czu.cz

\section{SHRNUTí}

Článek se zabývá kvantifikací emisí z benzínových motorů během dynamických režimů. Hlavními sledovanými emisemi jsou oxid uhelnatý a oxid uhličitý. Výsledkem je matematický model popisujicí produkci jednotlivých složek emisí ve všech režimech (statických i dynamických). Článek popisuje také postup pro stanovení emisí z provozních parametrů motoru. Výsledky jsou porovnání s jinými možnými způsoby zjištění produkce emisí.

\section{KLÍČOVÁ SLOVA: EMISE, DYNAMICKÝ REŽIM, NEPŘIMÁ METODA, MÍRA TRANSIENTNOSTI}

\section{ABSTRACT}

The article addresses the quantification of exhaust emissions from gasoline engines during transient operation. The main targeted emissions are carbon monoxide and carbon dioxide. The result is a mathematical model describing the production of individual emissions components in all modes (static and dynamic). It also describes the procedure for the determination of emissions from the engine's operating parameters. The result is compared with other possible methods of measuring emissions. The methodology is validated using the data from an on-road measurement. The mathematical model was created on the first route and validated on the second route.

\section{KEYWORDS: EMISSIONS, TRANSIENT MODE, INDIRECT METHOD, TRANSIENT RATE}

\section{INTRODUCTION}

The monitoring of the actual emissions of road vehicles during operation is important for reviewing the effectiveness of emissions control measures. One key control measure has been vehicle exhaust legislation. Legislated emission standards are defined over a synthetic laboratory driving cycle. However, real-world driving is more variable than that during the official New European Driving Cycle, with higher speeds and accelerations. [1]

The emissions and fuel consumption of light-duty vehicles have to be tested using prescribed cycles in order to be type-approved. This type-approval data is used to inform the customer and also serve as an input for models that predict the share of transportation in overall energy usage and production of emissions. However, several studies have shown that the type-approval data is not representative of real-world usage, because the current EU test cycles were not derived from real world in-use data and are not sufficiently dynamic. [2]
Nitrogen oxide emissions of modern light-duty diesel vehicles can be up to four times higher than type approval data $[3,4]$ and fuel consumption can be underestimated by up to $20 \%$ [5]. Variability in real-world tailpipe emissions for a given vehicle during its operation is associated with speed, acceleration, and road grade [6 -8], which are used to determine the Vehicle Specific Power (VSP) [9-11]. The U.S. Environmental Protection Agency's Motor Vehicle Emission Simulator (MOVES) model uses second-by-second speed, acceleration, and road grade to calculate VSP [12]. Currently, there is no standard procedure for quantifying road grade on a secondby-second basis from a moving vehicle. [13]

There are two basic options for monitoring vehicle emissions under real-world driving conditions - a direct method, using a portable emissions analyser or remote optical sensing, and an indirect method, using engine operating parameters and measured emission maps. 
Portable Emissions Measurement Systems (PEMS) are used to measure real-world tailpipe concentrations of carbon dioxide $\left(\mathrm{CO}_{2}\right)$, carbon monoxide $(\mathrm{CO})$, hydrocarbons $(\mathrm{HC})$, oxides of nitrogen $\left(\mathrm{NO}_{\mathrm{x}}\right)$ and particulate matter (PM).

The indirect method uses measured emission maps on motor stands and engine speed and load, [14] but this method does not account for transients.

The main purpose of this article was to determine the relationship between the production of $\mathrm{CO}$ and $\mathrm{CO}_{2}$ emissions and the operating parameters of the vehicle. The measurement was performed under laboratory conditions and a mathematical model has been presented from the measured values.

\section{MATERIALS AND METHODS}

Measurements were performed in the laboratory of the Department of Vehicles and Ground Transport of the Czech University of Life Sciences Prague. The measurement was performed on a three-cylinder gasoline engine, the basic characteristics of which are given in Table 1.

TABLE 1: Basic engine characteristics

TABULKA 1: Popis motoru

\begin{tabular}{ll} 
Engine code & AWY \\
\hline Construction & Three cylinder in row \\
\hline Compression ratio & $10.3: 1$ \\
\hline Max power & $40 \mathrm{~kW} @ 47501 / \mathrm{min}$ \\
\hline Max torque & $106 \mathrm{Nm} @ 30001 / \mathrm{min}$ \\
\hline ECU (engine control unit) & Simos 3PD (multipoint injector) \\
\hline Fuel & Petrol \\
\hline
\end{tabular}

TABLE 2: Basic dynamometer characteristics.

TABULLA 2: Popis dynamometru.

\begin{tabular}{ll} 
Dynamometer & \\
\hline Type & V125 \\
\hline RPM & $300-2500-80001 / \mathrm{min}$ \\
\hline Torque & $134-478-149.5 \mathrm{Nm}$ \\
\hline Power & $4.2-125-125 \mathrm{~kW}$ \\
\hline Strain Gauge & \\
\hline Nominal load & $2 \mathrm{kN}$ \\
\hline Culminated error & $0.5 \%$ of n.l. \\
\hline Reproducibility & $0.05 \%$ \\
\hline
\end{tabular}

The engine was connected to an eddy current dynamometer (technical parameters given in Table 2) on an engine test bench. The dynamometer allows simulation of different operating modes of the engine. Engine and dynamometer were connected and controlled using the Control Web software application (Moravian Instruments Inc.). This system allows remote control of the engine (simulation of accelerator pedal position to change the engine speed) and of the dynamometer (actuating current to change the engine load).

The instantaneous fuel consumption was measured by a WF005 in-line flow meter (Figure 1) with an output of 1800 pulses per liter of fuel.

The calculated production of $\mathrm{CO}_{2}$ was checked using formula 1 for calculation of fuel consumption. Due to the unknown chemical composition of the fuel and its density, the fuel

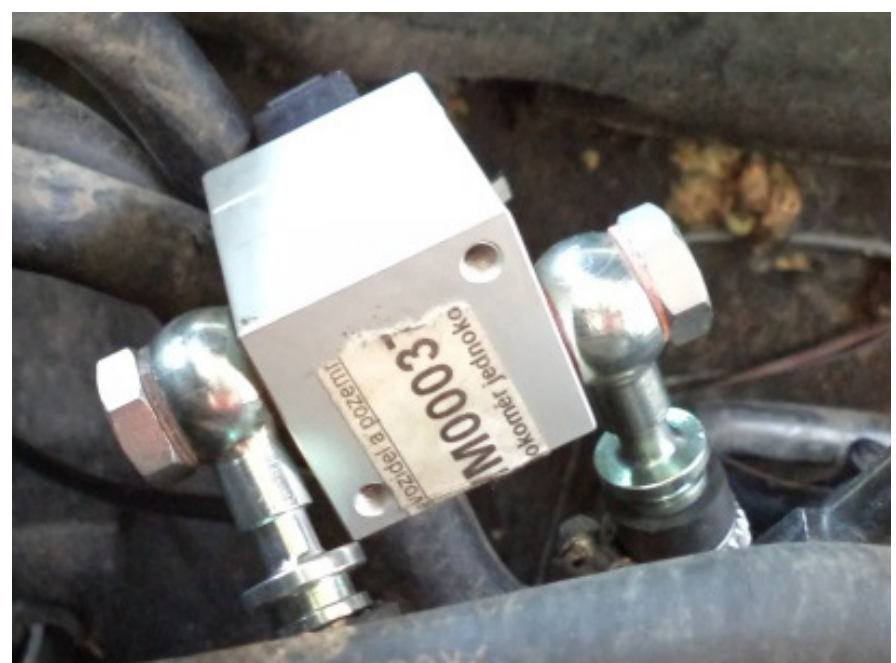

FIGURE 1: Connecting the flow meter to the fuel system. OBRÁZEK 1: Zapojení průtokoměru do palivového systému.

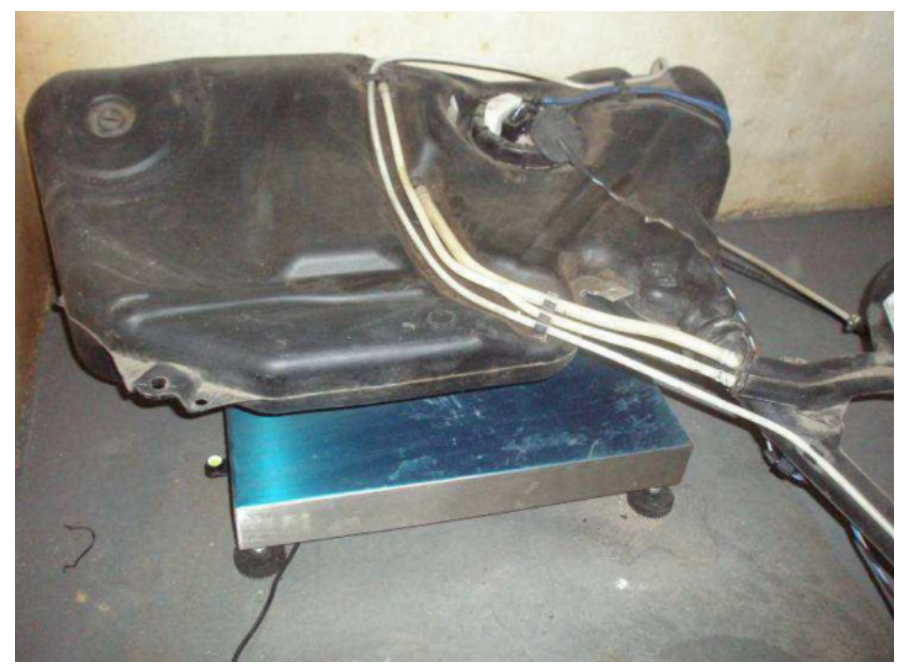

FIGURE 2: Fuel tank on scales.

OBRÁZEK 2: Palivová nádrž na plošinové váze. 
consumption was further measured on a mass basis with a platform scale (SOEHNLE, see Figure 2) on which the fuel tank was placed. The scale precision of $2 \mathrm{~g}$ was not sufficient for determining the instantaneous fuel consumption, but acceptable for determining the total fuel consumption during the entire cycle.

$$
m F U E L=\frac{m \mathrm{CO}_{2}}{3,11}
$$

where: $m F U E L$ weight of fuel consumed (g)

$$
\begin{array}{ll}
m \mathrm{mO}_{2} & \text { mass production of } \mathrm{CO}_{2}(\mathrm{~g}) \\
3,11 & \text { ratio of molecular weights of } \mathrm{CO}_{2} \text { and fuel } \\
& \text { (gasoline commercial grade) }
\end{array}
$$

Engine speed, engine load, intake air temperature and intake air pressure, necessary for further calculations, were obtained from the ECU (Engine Control Unit) with a VAG-COM diagnostic system and VCDS software (Figure 3).

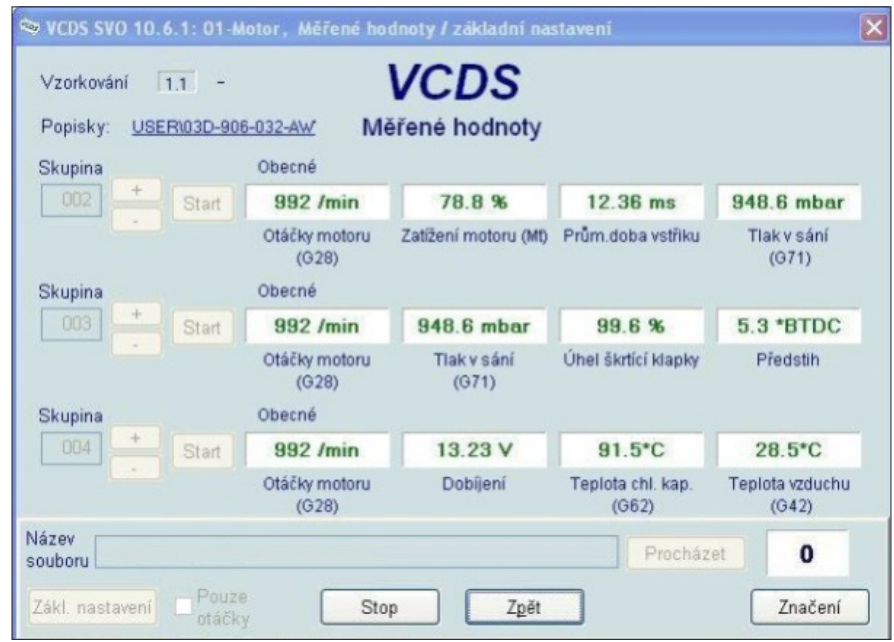

FIGURE 3: Software VCDS.

OBRÁZEK 3: Software VCDS.

Concentrations of hydrocarbons, carbon monoxide, carbon dioxide, nitrogen oxides and oxygen were measured by a PEMS emissions analyzer that evaluates emissions with a frequency of $1 \mathrm{~Hz}$. This involves analysis of exhaust gases based on direct measurements of physical and chemical properties of the monitored emissions components $\left(\mathrm{CO}, \mathrm{CO}_{2}, \mathrm{HC}-\mathrm{NDIR}\right.$ method, $\mathrm{O}_{2^{\prime}} \mathrm{NO}_{x}$ - an electrochemical cell). Results are obtained on a volume basis (\%, ppm). To obtain the mass production of emissions, a conversion is required (formulas 2 and 3) using values obtained from the ECU. [14]

$Q_{m v}=\frac{28,96 \cdot\left(p s-\frac{p_{a t m}}{\varepsilon}\right) \cdot V_{Z} \cdot \eta_{d} \cdot n}{600 \cdot i \cdot R \cdot T_{v z d}}$ where: $Q_{m v}$ the amount of air aspirated by engine $\left(\mathrm{g} \cdot \mathrm{s}^{-1}\right)$

28,96 molar mass of air $\left(\mathrm{g} \cdot \mathrm{mol}^{-1}\right)$

$p_{s} \quad$ intake pressure (mbar)

$p_{\text {atm }}$ atmospheric pressure (mbar)

$\varepsilon \quad$ engine compression ratio (1)

$V_{Z} \quad$ engine capacity $\left(\mathrm{dm}^{3}\right)$

$\eta_{d} \quad$ engine volumetric efficiency (1)

$n \quad$ engine speed $\left(\mathrm{min}^{-1}\right)$

600 constant conversion units (1)

$i \quad$ constant depending on engine type, $\mathrm{i}=1$ for twostroke engine, i = 2 for four-stroke engine (1)

$R$ universal gas constant $\left(\mathrm{J} \cdot \mathrm{mol}^{-1} . \mathrm{K}^{-1}\right)$, for an ideal gas $R=8,314$

$T_{v z d} \quad$ intake air temperature (K)

$M_{i}=\frac{\left(\frac{Q_{m v}}{28,96}+\frac{Q_{m p}}{14,17}\right) \cdot C_{i}}{100} \cdot Q_{i}$

where: $M_{i} \quad$ mass production of components of emissions (g. $\left.\mathrm{s}^{-1}\right)$

$Q_{m v}$ he amount of air aspirated by engine (g.s $\left.{ }^{-1}\right)$

$Q_{m p} \quad$ the amount of fuel supplied to the engine $\left(\mathrm{g} \cdot \mathrm{s}^{-1}\right)$

$C_{i} \quad$ concentration of one emission component in exhaust gas (\%)

28,96 molar mass of air $\left(\mathrm{g} \cdot \mathrm{mol}^{-1}\right)$

14,17 molar mass of fuel (g.mol $\left.{ }^{-1}\right)$, while the composition $\mathrm{C}_{1} \mathrm{H}_{1,89} \mathrm{O}_{0,016}$

$Q_{i} \quad$ molecular weight of one emission component in exhaust gas $\left(\mathrm{g} \cdot \mathrm{mol}^{-1}\right)$

\subsection{RATE OF TRANSIENT CO, EMISSION}

This indirect method uses the relationships between the production of emissions and engine operating parameters (RPM, load, change of RPM, change of load). In addition to these parameters, the change in emissions is reflected during transient modes. However, it is necessary to determine the relationship between the engine operating parameters and emissions. For these engine operating parameters it is essential to find a single value which reflects the strength of influence of each engine parameter. This value will be referred to as a transient rate.

A transient rate is specified as a ratio of engine operating parameters (RPM and load) that correlates best with the mass production of one specific emission component. Besides the speed and engine load it is further vital to reflect the rate of change of these values. For all of these values (RPM, change of RPM, load, change of load) it is necessary to find such factors in which the correlation coefficient between the transient rate and mass production of emissions will be as close as possible to 1 . These coefficients can be determined using an appropriate 
software tool, e.g. MS Office with add-in Solver. Each emission component has different coefficients. The transient rate for $\mathrm{CO}_{2}$ emission has been determined for the measured engine as:

$M T=2,23 \cdot n+100 \cdot M_{t}+1,4 \cdot\left(n_{2}-n_{1}\right)+119 \cdot\left(M_{t 2}-M_{t 1}\right)$

where: $M T$ transient rate (1)

$n \quad$ instantaneous engine speed $\left(\mathrm{min}^{-1}\right)$
$M_{t} \quad$ instantaneous engine load $(\%)$
$\left(n_{2}-n_{1}\right)$ changing of engine speed $\left(\mathrm{min}^{-1}\right)$
$\left(M_{t 2}-M_{t 1}\right)$ change of engine load $(\%)$
$2,23,100,1,4$ and 119 coefficients calculated with add-
$\quad$ in Solver (1)

The engine load level from the ECU has been used for the calculation of the transient rate. In this case (the engine on a test bench), the engine has been constantly loaded with the dynamometer's resistance. In addition, the engine was also loaded with the usual vehicle components such as an alternator, a coolant pump, etc. The total engine load is about $15 \mathrm{Nm}$.

To determine the instantaneous emissions during road operation it is sufficient to read engine speed and load from the ECU. With these values you can use formulas 2 and 3 to calculate the instantaneous mass of $\mathrm{CO}_{2}$ emission.

Comparison of the two indirect methods was done during the same cycle, during which the data was recorded from the ECU. These data were used for the calculated mass of $\mathrm{CO}_{2}$ emissions. To check the fuel flow meter (instantaneous fuel consumption), a PEMS analyzer (direct measuring method) and weight were used.

The relationship between the production of $\mathrm{CO}_{2}$, which is ascertained by the direct method, and the transient rate, calculated according to formula 4, is shown in Figure 4. If these points are approximated, we get a bisector where formula 5 expresses the mathematical relationship between the transient rate and mass of $\mathrm{CO}_{2}$ emission.

$m \mathrm{CO}_{2}-0,00049 \cdot \mathrm{MT}-1,6741$

where: $\mathrm{mCO}_{2}$ mass production of $\mathrm{CO}_{2}(\mathrm{~g})$

MT transient rate (1)

\subsection{TRANSIENT RATE FOR CO EMISSION}

$\mathrm{CO}$ emissions are not produced (measured behind a catalyst) in all engine operation modes. Therefore, it is crucial to determine the conditions under which the $\mathrm{CO}$ production shall be calculated. These conditions are summarized in the formula as follows: $\frac{n \cdot M_{t}}{10000} \quad<20$

where: $n \quad$ instantaneous engine speed $\left(\mathrm{min}^{-1}\right)$

$M_{t} \quad$ instantaneous engine load (\%)

In other cases it is possible to use the transient rate. For $\mathrm{CO}$ the formula with the most appropriate coefficients of transient rate is as follows:

$M T=0,75 \cdot n+99,4 \cdot M_{t}-0,6 \cdot\left(n_{2}-n_{1}\right)+30,8 \cdot\left(M_{t 2}-M_{t 1}\right)$

Figure 5 shows the process of $\mathrm{CO}$ production (by direct method) and the transient rate during the cycle which satisfies the conditions outlined in formula 6 .

Figure 6 represents a relationship between the $\mathrm{CO}$ production which has been determined by the direct method and the transient rate calculated according to formula 7 .

This relationship is not linear and it is necessary to use 3 formulas to calculate mass of $\mathrm{CO}$ production. All formulas are shown in Table 3.

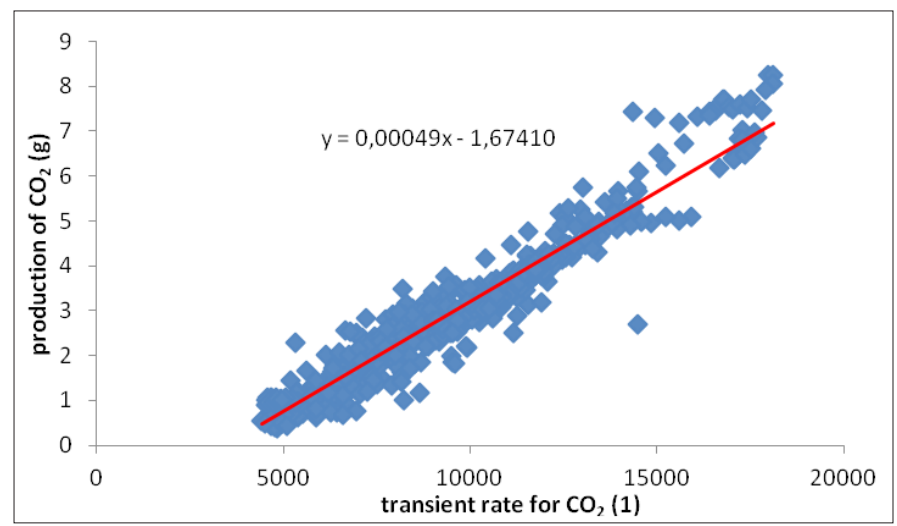

FIGURE 4: Relationship between mass production of $\mathrm{CO}_{2}$ and transient rate for $\mathrm{CO}_{2}$.

OBRÁZEK 4: Závislost hmotnostní produkce $\mathrm{CO}_{2}$ na míre transientnosti $\mathrm{CO}_{2}$.

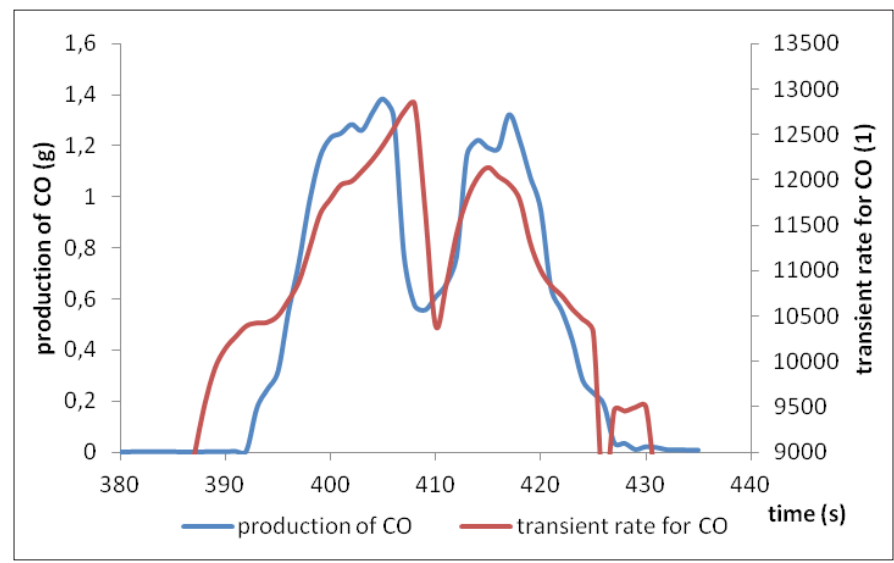

FIGURE 5: Process of CO production and transient rate for $\mathrm{CO}$. OBRÁZEK 5: Průběh produkce emisí CO a míry transientnosti CO. 
TABLE 3: Mathematical model of CO production.

TABULKA 3: Matematický model produkce CO.

\begin{tabular}{rlr} 
Transient rate $(-)$ & CO production (g) \\
\hline$\frac{n \cdot M_{t}}{10000}<20 ; M T \leq 9600$ & $m C O=0$ \\
$9600<M T \leq 10300$ & $\left.m C O=0,00001 \cdot M T-0,095655^{\star}\right)$ \\
$10200<M T<11000$ & $m C O=0,001 \cdot M T-10,15467$ \\
$M T \geq 11000$ & $m C O=0,00026 \cdot M T-1,92438$
\end{tabular}

*) For simplification can be used $\mathrm{mCO}=0,005$.

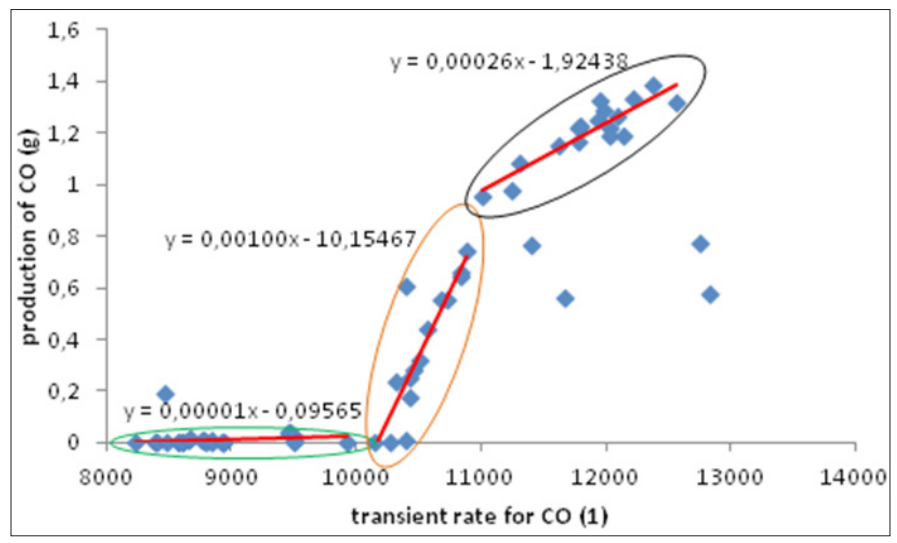

FIGURE 6: Relationship between mass production of $\mathrm{CO}$ and the transient rate for $\mathrm{CO}$.

OBRÁZEK 6: Závislost hmotnostní produkce CO na míře transientnosti CO.

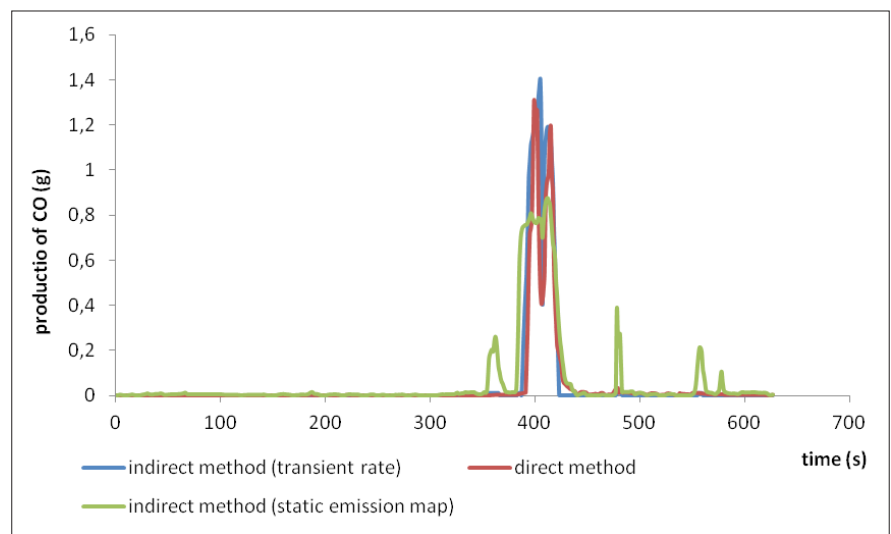

FIGURE 7: Comparison of production of $\mathrm{CO}$ emissions.

OBRÁZEK 7: Porovnání produkce emisí CO.

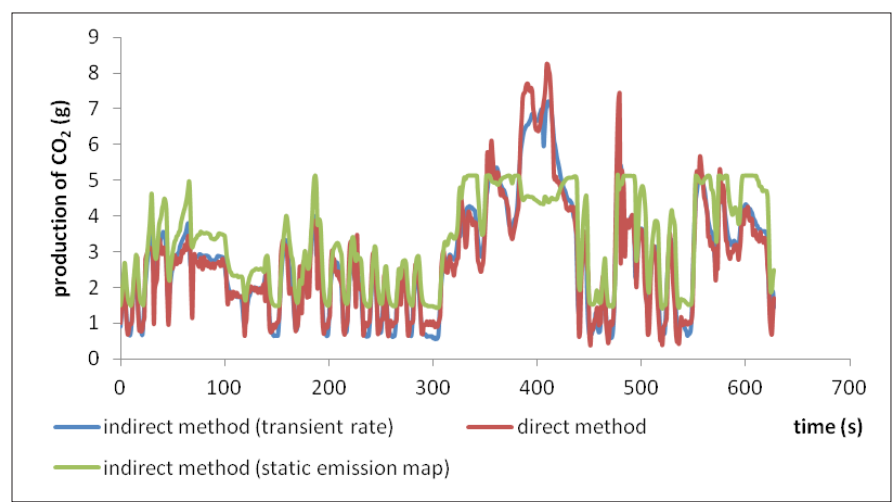

FIGURE 8: Comparison of production of $\mathrm{CO}_{2}$ emissions.

OBRÁZEK 8: Porovnání produkce emisí $\mathrm{CO}_{2}$.

\section{RESULTS}

Calculation of emissions by transient rate was compared to the other methods of measuring emissions - both direct and indirect methods. This comparison allows us to evaluate the accuracy of this method.

\subsection{COMPARISON OF CO EMISSIONS}

The production of $\mathrm{CO}$ observed in various ways is shown in Figure 7.

As seen in Figure 7, the error from the estimation (calculation) of $\mathrm{CO}$ using emission characteristics determined at steady speeds (static emission map) has a greater magnitude (correlation coefficient 0.82 ) than the error from the calculation of $\mathrm{CO}$ production using the terms and equations set out in Table 3 (correlation coefficient 0.94).

As a result, the calculated $\mathrm{CO}$ production correlates fairly well with the values determined by the direct method of measurement.

If we take into consideration the total $\mathrm{CO}$ emissions during the entire cycle, the value obtained by calculation using the direct method is 25.52 grams. Using indirect methods for

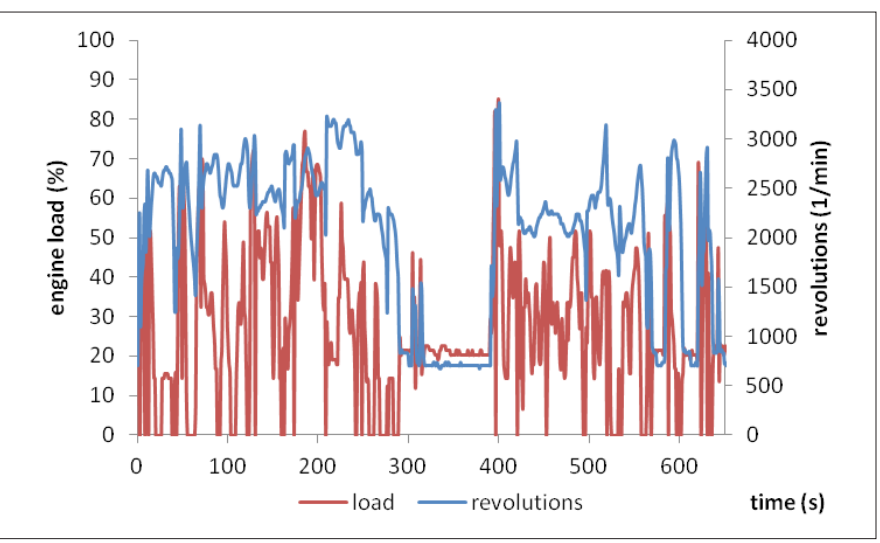

FIGURE 10: A plot of engine speed and load. OBRÁZEK 10: Průběh otáček a zatížení motoru.

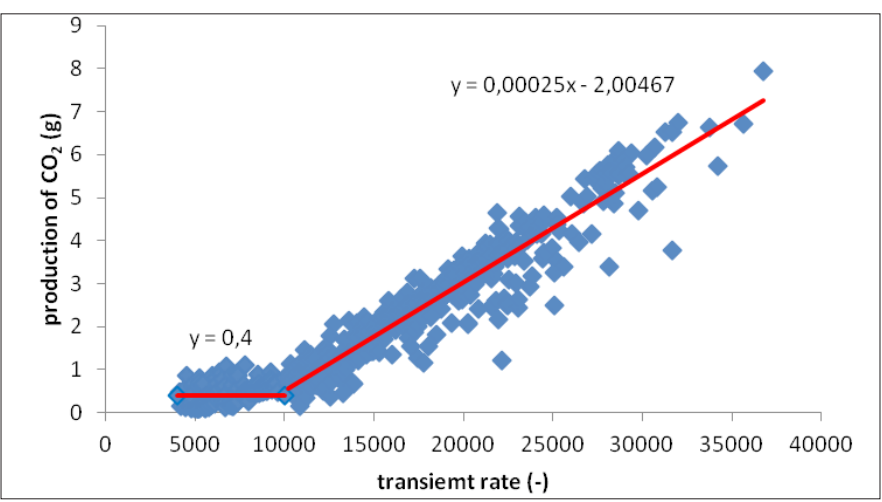

FIGURE 11: $\mathrm{CO}_{2}$ production as a function of the transient rate. OBRÁZEK 11: Závislost produkce emisí $\mathrm{CO}_{2}$ na míře transientnosti. 


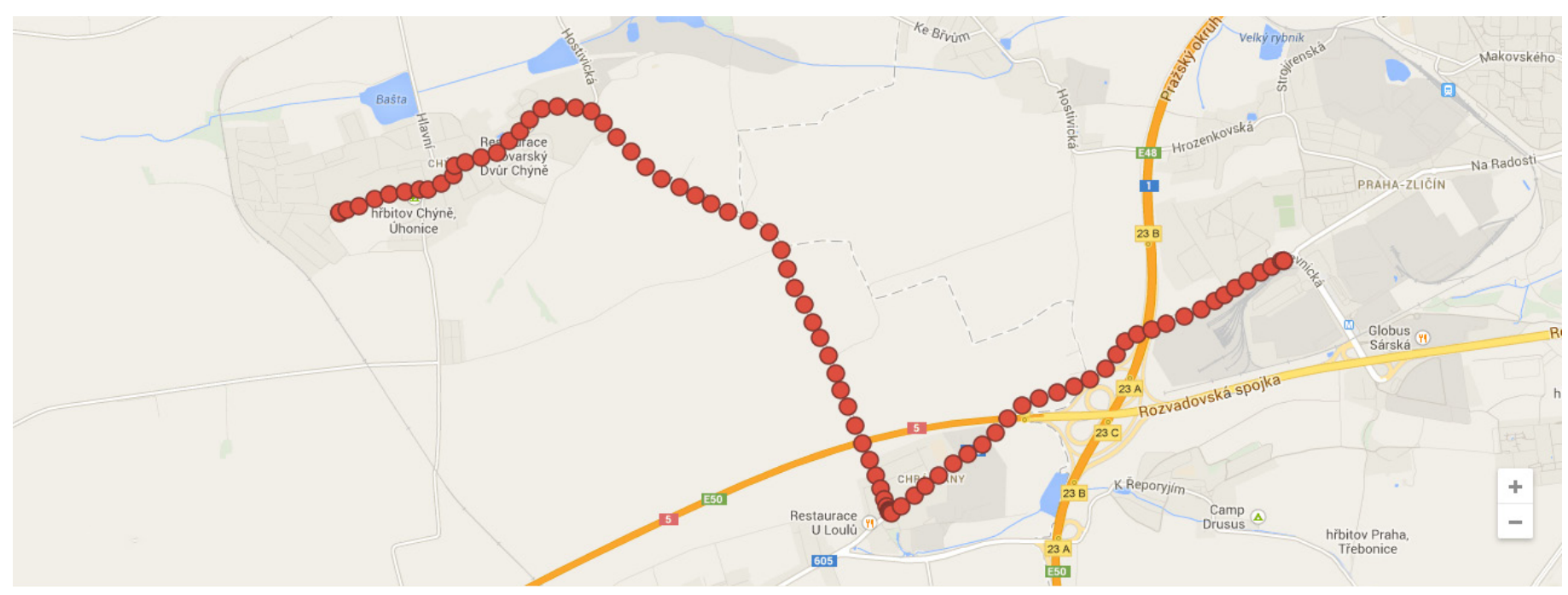

FIGURE 9: The data collection route for creating a mathematical model.

OBRÁZEK 9: Trasa sběru dat pro vytvoření matematického modelu.

measuring emissions the summaries of total production are $31.65 \mathrm{~g} \mathrm{CO}$ (calculated by the transient rate) and $38.74 \mathrm{~g}$ (reading from a static emission map).

\subsection{COMPARISON OF CO EMISSIONS}

Applying the transient rate for calculation of $\mathrm{CO}_{2}$ production presents more accurate results than using the static emission map. The correlation coefficient between the values determined by the direct method and indirect method by transient rate is 0.97 . When comparing the values determined by the direct method and indirect method by static emission map correlation, the coefficient is only 0.81 . The production of $\mathrm{CO}_{2}$ observed in various ways is shown in Figure 8.

Total $\mathrm{CO}_{2}$ emissions during the cycle calculated by the direct method was $1744 \mathrm{~g} . \mathrm{CO}_{2}$ emissions determined by an indirect method using the transient rate was $1756 \mathrm{~g}$ and by static emission map production of $\mathrm{CO}_{2}$ was $2085 \mathrm{~g}$.

To check the calculation of $\mathrm{CO}_{2}$ emissions formula 1 can be used for the calculation of fuel consumption. These values detected in this manner can be compared with the value from the flowmeter in the fuel system. From the flowmeter the fuel consumption is $560 \mathrm{~g}$. If the fuel consumption is calculated

TABLE 4: A mathematical model of $\mathrm{CO}_{2}$ production for on-road operations. TABULKA 4: Matematický model produkce emisí $\mathrm{CO}_{2}$ pro silniční provoz.

\begin{tabular}{cc} 
Transient rate $(-)$ & $\mathrm{CO}_{2}$ production $(\mathrm{g})$ \\
\hline$M T<10000$ & 0,4 (for simplification) \\
\hline$M T \geq 10000$ & $0,00024 \cdot M T-2,00741$ \\
\hline
\end{tabular}

(using formula 1) from $\mathrm{CO}_{2}$ emissions, the results for fuel consumption is approximately $565 \mathrm{~g}$ (indirect method using the transient rate), $561 \mathrm{~g}$ (by direct method) and $670 \mathrm{~g}$ (indirect method using static emission map).

\subsection{VERIFICATION OF THE METHODOLOGY DURING AN ON-ROAD TEST MEASUREMENT}

The verification was performed on a Škoda Fabia 1.2 HTP car using the same diagnostic systems as in laboratory conditions, i.e. PEMS analyzer VMK, Flowmeter WF005 and diagnostic system VAG-COM.

The mathematical model was determined based on the data measured and collected on-road taking a route from Chýně to Zličín (Figure 9).

A sufficient number of data samples with different combinations of engine operating parameters were collected whilst driving this route. A plot of engine speed and load is shown in Figure 10.

The transient rate of this specific vehicle has been obtained from the collected data. The $\mathrm{CO}_{2}$ emissions transient rate is as follows:

$$
M T_{\mathrm{CO}_{2}}-2,8 \cdot n+310 \cdot M+2,1 \cdot\left(n_{2}-n_{1}\right)+76 \cdot\left(M_{2}-M_{1}\right)
$$

The immediate level of emissions and the intensity of the transient rate was calculated according to formulas 2 and 3 for each time moment during the measurement. The relationship between these values was plotted on a graph (Figure 11) and subsequently the conditions for calculating $\mathrm{CO}_{2}$ emissions were determined using the indirect method. 

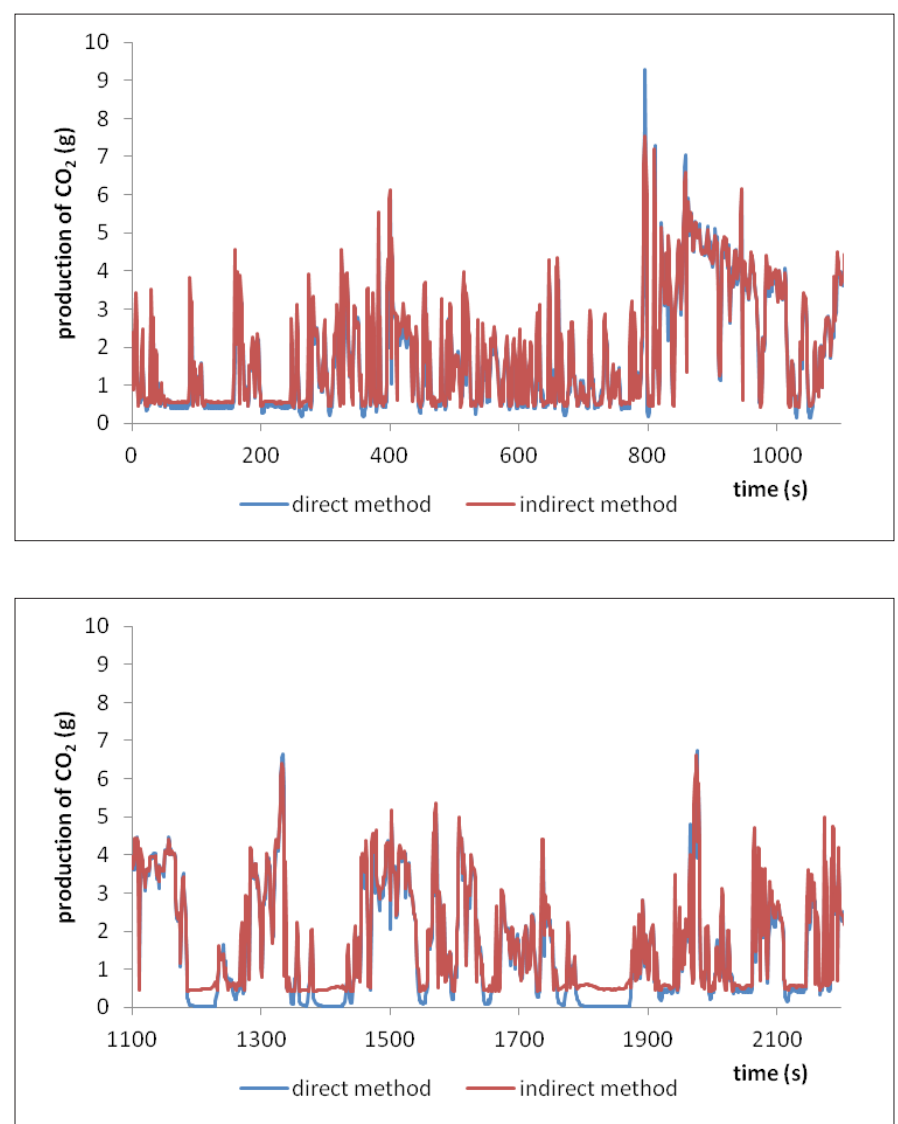

FIGURE 14: A comparison of $\mathrm{CO}_{2}$ production on a verification route. OBRÁZEK 14: Srovnání produkce emisí $\mathrm{CO}_{2}$ na ověrovací trase.

TABLE 5: Evaluation of different methods of measuring emissions. TABULKA 5: Vyhodnocení produkce emisí různými metodami

\begin{tabular}{|cc|}
\hline Transient rate $(-)$ & Co Production $(\mathrm{g})$ \\
\hline$M T<10000$ & 0,01 (for simplification) \\
\hline $10000 \leq M T<15000$ & $4 \cdot 10^{-6} \cdot M T-0,03$ \\
\hline$M T \geq 15000$ & $7 \cdot 10^{-6} \cdot M T-0,0075$ \\
\hline
\end{tabular}

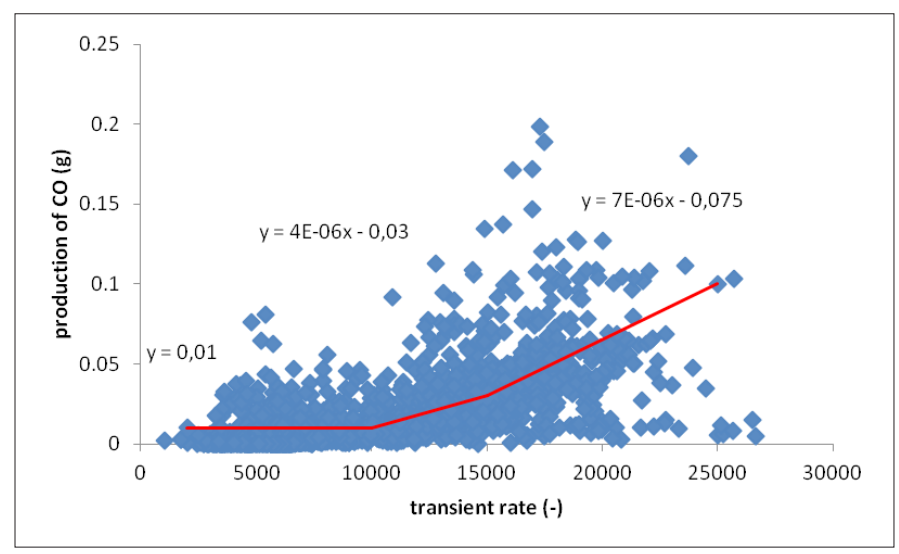

FIGURE 12: CO emission production as a function of transient rate. OBRÁZEK 12: Závislost produkce emisí CO na míre transientnosti.
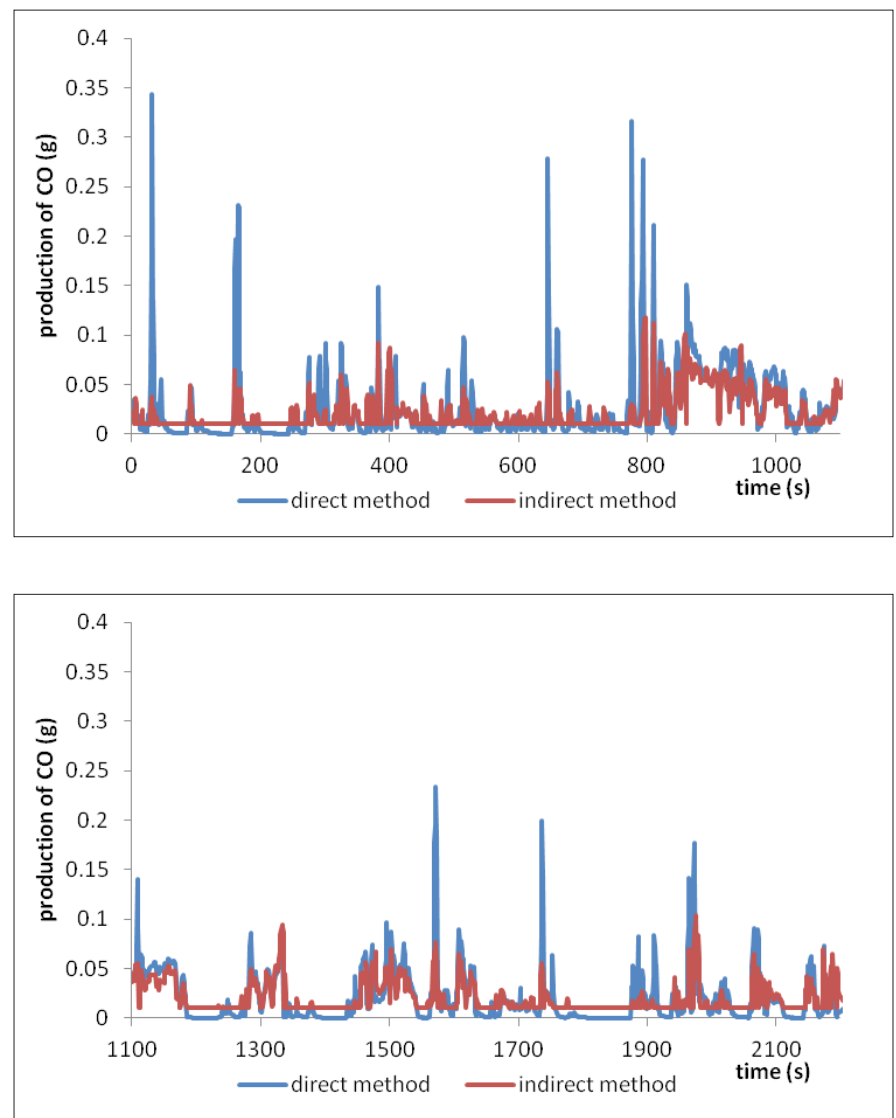

FIGURE 15: A comparison of CO production on a verification route. OBRÁZEK 15: Srovnání produkce emisí CO na ověřovací trase.

A mathematical model of $\mathrm{CO}_{2}$ emissions during the on-road operation is as follows:

The calculation of $\mathrm{CO}$ emissions was similarly processed and evaluated. A transient rate of $\mathrm{CO}$ emissions is the following:

$M T_{C O}-1,9 \cdot n+225 \cdot M+1,1 \cdot\left(n_{2}-n_{1}\right)-12 \cdot\left(M_{2}-M_{1}\right)$

The relationship between $\mathrm{CO}$ production and transient rate is shown in Figure 12. In this case a correlation coefficient of 0.68 has been achieved; a lower degree of accuracy can be assumed in the calculation of the $\mathrm{CO}$ emissions. The mathematical model of $\mathrm{CO}$ emissions is shown in Table 5.

The verification of these mathematical models was checked on route from Kralupy nad Vltavou to Praha-Dejvice (Figure 13). Driving time was 37 minutes and the distance $24.7 \mathrm{~km}$.

The development of $\mathrm{CO}_{2}$ and $\mathrm{CO}$ production over time is presented in Figures 14 and 15. A comparison of the results obtained by mathematical models and by the direct method is shown in Table 6. 


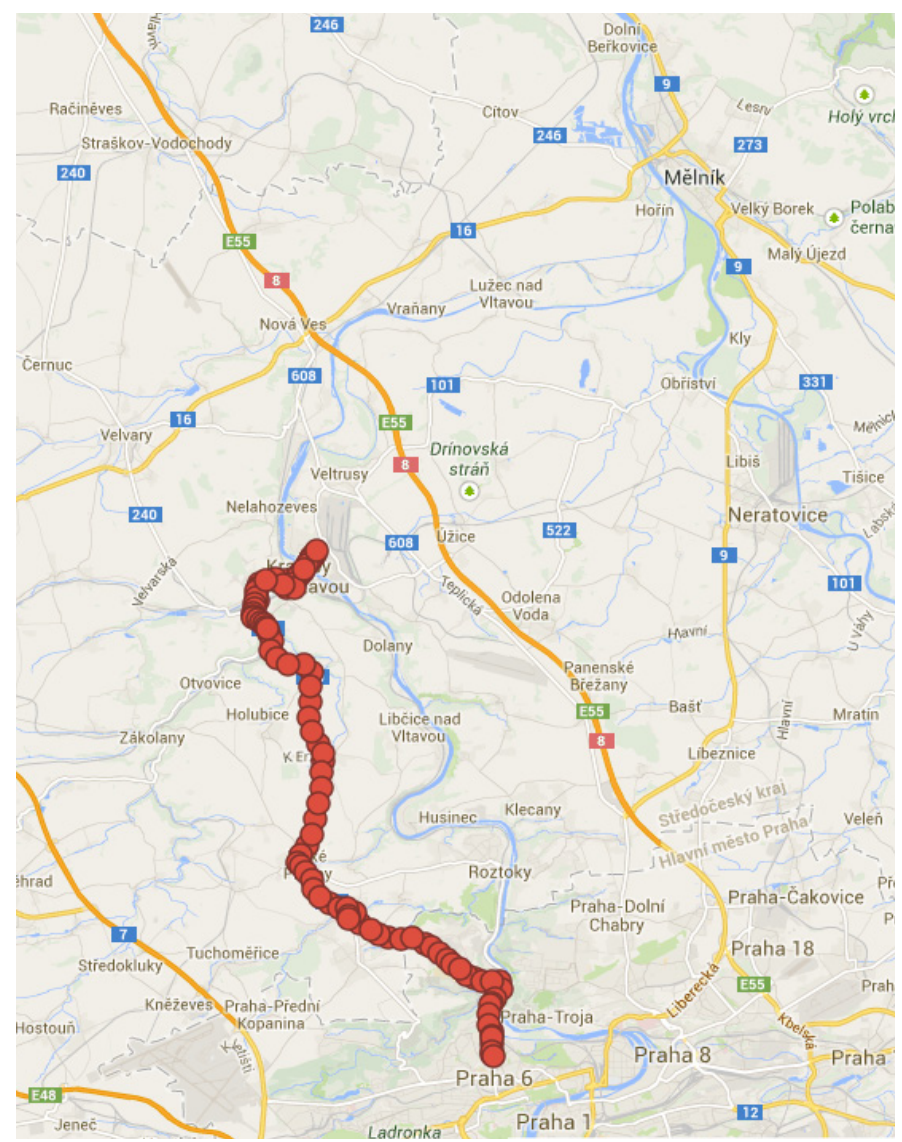

FIGURE 13: Route for verification of the mathematical model. OBRÁZEK 13: Trasa pro ověření matematického modelu.

\section{DISCUSSION}

Currently, there are two basic principles for determining emissions volume during real-world driving. The first method is the direct measurement of emissions, which uses exhaust gas analysis and recording of the concentration of the individual emissions components. The major disadvantage of this measurement method is the necessity of using an analyzer (PEMS), which is very expensive and using this method of measurement is not suitable for all vehicles.

The second method of measurement (the indirect method) uses the measured emission characteristics (static emission maps) and according to engine operating parameters determines the output of the emission constituents. This method is easy in respect of the instrumentations and it is possible to use it on a larger scale. This method implicitly works with emission maps measured during static engine modes. A difference is assumed between the static and transient modes during emissions measurement with the static emission maps. Therefore, the results are not fully accurate. The above-presented methodology for creating a mathematical model cannot provide absolute accuracy of the calculation of the produced emissions, but it is sufficiently precise and works with a limited number of parameters. Should more accurate results need to be obtained a more complex mathematical model would be developed and/or the monitoring and measurement of other parameters affecting the emission levels (e.g. engine temperature, catalyst temperature, the exact composition of the fuel etc.).

\section{CONCLUSION}

By the introduction and utilization of the transient rate, the change of speed and change of load is used together with the engine speed and engine load, which leads to more accurate results when using the indirect method of measurement, as shown in the Table 7.

Using the transient rate to calculate emissions production by the indirect method can achieve more accurate results compared to the indirect method without using the transient rate. Refinement can be up to $28 \%$ in $\mathrm{CO}$ emissions and up to $19 \%$ in $\mathrm{CO}_{2}$ emissions (in our case).

For calculation of the transient rate it is important to have sufficiency of the measured and processed data and for calculation of $\mathrm{CO}$ to have correctly determined conditions for evaluation. It can be assumed that the coefficients are not generally applicable, but are only valid for the tested engine type. Moreover, it is likely that the coefficients will change with the technical state of the engine.

However, the indirect method of measuring emissions using transient rate includes many unknown parameters such as the engine operating temperature, air humidity, technical condition

TABLE 6: A comparison of $\mathrm{CO}_{2}$ and $\mathrm{CO}$ total production and fuel consumption. TABULKA 6: Porovnání celkové produkce emisí $\mathrm{CO}_{2}$ a $\mathrm{CO}$ a spotřeby paliva.

\begin{tabular}{|lccc|} 
& \multicolumn{2}{l}{$\mathrm{CO}_{2}$} & \multicolumn{2}{l}{$\begin{array}{l}\text { Fuel } \\
\text { production }(\mathrm{g})\end{array}$} & $\begin{array}{l}\text { production }(\mathrm{g}) \\
\text { consumption }(\mathrm{g})\end{array}$ \\
\hline Direct method & 3723 & 49,9 & 1222 \\
\hline By transient rate & 3674 & 34,7 & 1199 \\
\hline Flowmeter & - & - & 1165 \\
\hline
\end{tabular}

TABLE 7: Evaluation of different methods of measuring emissions (laboratory conditions).

TABULKA 7: Vyhodnocení produkce emisí různými metodami (laboratorní podmínky).

\begin{tabular}{|ccccc} 
& $\begin{array}{l}\text { Direct } \\
\text { method }\end{array}$ & $\begin{array}{l}\text { Indirect method } \\
\text { (static emission map) }\end{array}$ & $\begin{array}{c}\text { Indirect method } \\
\text { (transient rate) }\end{array}$ & Refinement \\
\hline $\mathrm{CO}$ & $25,52 \mathrm{~g}$ & $38,74 \mathrm{~g}$ & $31,65 \mathrm{~g}$ & $27,78 \%$ \\
\hline $\mathrm{CO}_{2}$ & $1744 \mathrm{~g}$ & $2085 \mathrm{~g}$ & $1756 \mathrm{~g}$ & $18,86 \%$ \\
\hline
\end{tabular}


of the engine, the chemical composition of the fuel, etc. Despite of these shortcomings, more accurate data are obtained compared to the alternative without use of the transient.

\section{REFERENCES}

[1] Cheny Y. and Borken-Kleefeld J. (2014) Real-driving emissions from cars and light commercial vehicles Results from 13 years remote sensing at Zurich/CH, In: Atmospheric Environment, Vol. 88, May 2014, pp. 157-164. ISSN 1352-2310.

[2] Demuynck J., Bosteels D., Paepe M., Favre C., May J. and Verhelst S. (2012). Recommendations for the new WLTP cycle based on an analysis of vehicle emission measurements on NEDC and CADC, In: Energy Policy, Vol. 49, October 2012, pp. 234-242. ISSN 0301-4215.

[3] Joumard R., André M., Vidon R., Tassel P. and Pruvost C. (2000). Influence of driving cycles on unit emissions from passenger cars, In: Atmospheric Environment, Vol. 34, Issue 27, pp. 4621-4628. ISSN 1352-2310.

[4] Weiss M., Bonnel P., Hummel R., Provenza A. and Manfredi U. (2011). On-road emissions of light-duty vehicles in Europe, In: Environmental Science and Technology, Vol. 45, Issue 19, pp. 8575-8581. ISSN 0013-936X.

[5] Pelkmans L. and Debal P. (2006). Comparison of onroad emissions with emissions measured on chassis dynamometer test cycles, In: Transportation Research Part D: Transport and Environment, Vol. 11, Issue 4, pp. 233-241. ISSN 1361-9209.

[6] Pierson W., Gertler A., Robinson N., Sagebiel J., Zielinska B., Bishop G., Stedman D., Zweidinger R. and Ray W. (1996). Real-world automotive emissions-Summary of studies in the Fort McHenry and Tuscarora mountain tunnels, In: Atmospheric Environment, Vol. 30, Issue 12, pp. 2233-2256. ISSN 1352-2310.

[7] Zhang K. and Frey H. (2006). Road Grade Estimation for On-Road Vehicle Emissions Modeling Using Light Detection and Ranging Data, In: Journal of the Air, Vol. 56, Issue 6, pp. 777-788. ISSN 1096-2247.

[8] Boroujeni B., Frey H. and Sandhu G. (2013). Road Grade Measurement Using In-Vehicle, Stand-Alone GPS with Barometric Altimeter, In: Journal of Transportation Engineering, Vol. 139, Issue 6, pp. 605-611. ISSN 1934-5436.

[9] Jiménez-Palacios J. L. (1999). Understanding and Quantifying Motor Vehicle Emissions with Vehicle Specific Power and TILDAS Remote Sensing. Cambridge, MA: Massachusetts Institute of Technology, Ph.D. Thesis.

[10] Huai T., Durbin T. D., Younglove T., Scora G., Barth M. and Norbeck J. (2005). Vehicle Specific Power Approach to Estimating On-Road $\mathrm{NH}_{3}$ Emissions from Light-Duty Vehicles. In: Environmental Science and Technology, Vol. 39, Issue 24, pp. 9595-9600. ISSN 0013-936X.

[11] Frey H., Rouphail N., Zhai H., Scora G., Barth M. and Norbeck J. (2006). Speed and Facility Specific Emission Estimates for On-Road Light-Duty Vehicles on the Basis of Real-World Speed Profiles, In: Transportation Research Record: Journal of the Transportation Research Board, Vol. 1987, pp. 128-137. ISSN 0361-1981.

[12] Vallamsundar S. and Lin J. (2011). MOVES versus MOBILE: comparison of greenhouse gas and criterion pollutant emissions, In: Transportation Research Record: Journal of the Transportation Research Board, Vol. 2233, pp. 27-35, ISSN 0361-1981.

[13] Boroujeni B. and Frey H. (2014). Road grade quantification based on global positioning system data obtained from real-world vehicle fuel use and emissions measurements, In: Atmospheric Environment, Vol. 85, pp. 179-186. ISSN 1352-2310.

[14] Kotek, M. (2012). The proposal of method for a measuring motor vehicles' emissions under operational conditions. Prague: Czech University of Life Sciences, Faculty of Engineering, Department Vehicles and Ground Transport, Ph.D. Thesis. 